\title{
Publishers, legal deposit and the changing publishing environment.
}

\author{
MUIR, A.
}

2020

This is a preprint of a chapter accepted for publication by Facet Publishing. This extract has been taken from the author's original manuscript and has not been edited. The definitive version of this piece may be found in Electronic Legal Deposit: Shaping the Library Collections of the Future, Facet, London. ISBN 9781783303779 which can be purchased from http://www.facetpublishing.co.uk/title.php?id=303779\&category_code=37. The author agrees not to update the preprint or replace it with the published version of the chapter. Our titles have wide appeal across the UK and internationally and we are keen to see our authors content translated into foreign languages and welcome requests from publishers. World rights for translation are available for many of our titles. To date our books have been translated into over 25 languages. 


\section{Publishers, Legal Deposit and the Changing Publishing Environment}

\section{Adrienne Muir, Robert Gordon University, UK}

\section{Introduction}

UK publishers have always had mixed attitudes to legal deposit. This chapter focuses on electronic legal deposit in the UK from the perspective of publishers, providing some assessment of what the impact on publishers has been in the relatively short time electronic legal deposit has been in existence, and the role of legal deposit in a dynamic digital environment.

The long opposition to legal deposit requirements from the publishing industry is well documented. Feather's historical account (1994, pp. 97121) brings into sharp focus the often vehement opposition of the publishing trade to the principle of legal deposit, and the trade's history of reluctant or non-compliance with the law. At the beginning of the 19th century, the amount of material being deposited was unsatisfactory for the deposit libraries. Anthony Panizzi, the principal librarian of the British Museum, through his energetic enforcement of legislation, established what may be regarded as 'proper' legal deposit in the UK (Altick 1957, p. 215, Harris 1991) with more comprehensive compliance with the law.

The mid-twentieth century saw the advent of electronic publishing. This was initially limited to textual and numeric data, but increasingly it has incorporated recorded sound and still and moving images. The development of the world wide web and browser software in the 1990s and other developments has profoundly affected publishing practices (Brown and Boulderstone 2008; Deegan and Sutherland 2009; Martin and Tian 2010; Ramrattan and Szenberg 2016). It became clear that restricting legal deposit to print publications would result in an increasingly large gap in the national legal deposit archive. The British Library $(B L)$ commissioned several studies on potential issues arising from the extension of legal deposit to non-print publications (Electronic 
Publishing Services Ltd 1996, Hendley 1996, Martin 1996). The BL (1996), supported by the other legal deposit libraries and the British Film Institute, then submitted a proposal to the UK government to extend legal deposit to non-print publications.

Publishing is an important contributor to the UK economy. The Publishers Association (2019) reported that book and academic journal publishing income was $£ 6$ billion in 2018 and that there was "a 3\% increase in digital sales income (to $£ 2.6 \mathrm{bn}$ ) and a $5 \%$ drop in physical sales (to $£ 3.4 \mathrm{bn}$ )". The publishers' report to the five year post implementation review of deposit of non-print publications states that the publishing industry creates $£ 7.8$ billion gross value added (GVA), supports more than 70,000 jobs and that $57 \%$ of total publishing turnover ( $£ 29$ billion) comes from exports. The industry has an annual trade surplus of $£ 1.1$ billion (Joint Committee on Legal Deposit 2018, p. 57). The publishing voice is, therefore, a strong one, and tensions between increased digital outputs and electronic deposit requirements have emerged, with the proposed extension of the scope of the law reviving publisher concerns about legal deposit. For example, Whitaker (2001a) described legal deposit as a tax on knowledge and questioned why the industry is penalised in this way. In a later article, Whitaker (2001b) accepted that an archive of published output is a national good, but he did not agree that publishers should be providing the books for free, and repeated that legal deposit is an anomalous tax in kind on the publishing industry. However, the financial burden is not borne solely by the publishers; the State funds the accessioning, cataloguing, storage and preservation of publications by legal deposit libraries and the creation of national bibliographies. Dellar (2001) also pointed out that deposit obligations are factored into business planning, as review copies are.

However, despite the concerns voiced by the publishing industry, the UK Government acknowledged the need to expand the scope of legal deposit and new legislation was proposed. UK legal deposit libraries and publishers collaboratively undertook preparatory work leading to the new legislation and publisher concerns were taken into account throughout the 
process. This was a long process, involving negotiation between the interested parties as well as exploration of how deposit of electronic publications could work in practice. This chapter provides an overview of the relationship of e-legal deposit frameworks to the publishing industry, including preparation for legislation and the history of negotiations, the working approach taken to electronic legal deposit, the impact upon publishers, and the place of electronic legal deposit in a developing publishing landscape, which includes the intersection of open access, open science, commercial publishing, and user expectations.

\section{Preparing for Legislation}

In January 1998, the UK Government announced the establishment of a working party (Working Party on Legal Deposit 1998, s. 1.8), including the legal deposit libraries and publishers Reuters, Thomson Science ${ }^{1}$ and Chadwyck-Healy. Its remit was to:

- advise on how to achieve a comprehensive national archive of nonprint material, taking into account the concerns of publishers and exploring the potential for the use of secure networking for access;

- draw up and agree a voluntary code of practice for digital and microform material, to be used until government introduced legislation;

- ensure compatibility between the provisions of this code of practice and existing voluntary arrangements for film and sound material

The main UK trade associations, the Publishers Association (PA), the Association of Learned and Professional Society Publishers (ALPSP) and the Periodical Publishers Association (now known as the Professional Publishers Association), endorsed the voluntary code of practice developed by the Working Party (1999) ${ }^{2}$. These associations between them represented for and non-profit and independent consumer,

\footnotetext{
${ }^{1}$ Two separate companies at the time, since merged to form Thomson Reuters.

2 This version of the code is no longer available online, the 2000 version is available at http://www.bl.uk/aboutus/stratpolprog/legaldep/voluntarydeposit/
} 
educational, scholarly and media magazine publishers. The voluntary code came into effect on 4 January 2000. Publisher representatives and the legal deposit libraries continued to work together in a Joint Committee on Voluntary Deposit set up to monitor the voluntary deposit scheme and work on issues arising in its operation.

The Legal Deposit Libraries Act 2003 was enabling legislation for the subsequent extension of legal deposit from print to other forms of publication through secondary legislation. A range of concerns about the potential impact of extending the scope of legal deposit was raised during the draft legislation's passage through Parliament (Muir 2005, pp. 32-42). The Act (s. 11) stated that secondary legislation made to extend the scope of legal deposit to non-print publications should not introduce a disproportionate interference with the economic interest of publishers. The $\mathrm{BL}$ press release announcing the new primary legislation indicated that the publishers were reassured by the Government's responses to their concerns during the passage of the legislation through Parliament (Mills Wade 2003).

A Joint Committee on Legal Deposit (JCLD) superseded the Joint Committee on Voluntary Deposit. The membership now also included publisher associations reflecting the wider publishing industry: the International Association of Scientific, Technical \& Medical Publishers; the Newspaper Publishers Association and the Newspaper Society ${ }^{3}$ (two organisations now merged into News Media Association) and the Association of Online Publishers (British Library 2018a). The Association of Online Publishers (2019) represents publishers across the press, broadcasting and "pure online media". The JCLD discusses all aspects of legal deposit, but a major role at the beginning of its existence was to advise the Government's Advisory Panel for "ongoing legislation on legal deposit" (Fell 2004).

\footnotetext{
${ }^{3}$ Now merged into News Media Association.
} 


\section{The Legal Deposit Advisory Panel}

The Legal Deposit Advisory Panel (LDAP) began its work in 2005 and submitted its final recommendation for secondary legislation in 2010. LDAP comprised fifteen members: legal deposit library representatives; publisher representatives and five independent members ${ }^{4}$. LDAP had to identify, understand and work through some complex issues and this process was not without its challenges. Progress was reported through annual reports (Legal Deposit Advisory Panel 2006, 2007, 2008). Challenges arose because the print publishing paradigm did not transfer well to a rapidly changing digital environment. Difficulties included what "published in the United Kingdom" means in an online networked environment (Green 2012, p. 107). The fluid nature of digital publishing also made it difficult to consider traditional publication categories in isolation from each other (Green 2012, p. 107).

One of LDAP's core tasks in its first year was to address the "territoriality" issue. This was done in consultation with other parties, including the JCLD and the Federation of European Publishers/Conference of European National Libraries Committee (FEP/CENL) ${ }^{5}$. LDAP also commissioned a report on the "universe" of digital publications eligible for legal deposit (Electronic Publishing Services 2006). This report proposed a typology which split publications into two categories: granular and enquiry driven. These categories acknowledged that digital publications may consist of several discrete components or may be constructed through interrogation of databases (Electronic Publishing Services 2006, p. 7-8). Further considerations included whether publications are made available offline or online and whether they are made freely available or protected in some way. This approach facilitated progress by highlighting issues including commercial concerns, how different types of content could be acquired

\footnotetext{
${ }^{4}$ The author was an independent member of LDAP from 2005 to 2008.

${ }^{5}$ This joint committee's mandate includes monitoring legislation and practice and providing advice in the context of voluntary and statutory deposit schemes. The Committee's most recent joint statement includes reference to publication formats and territoriality issues, see: https://fep-fee.eu/FEP-andCENL-adopt-joint-statement
} 
and what additional material, such as software or manuals, would need to be deposited along with content.

LDAP's work initially focused on offline publications, such as microforms and optical discs, freely available (web) publications, and electronic journals. The existing voluntary scheme for offline non-print publications was simplified to ease the burden on participating publishers (2006). The aim was to invigorate participation and to gather evidence to inform whether deposit of offline material should continue to be on a voluntary or statutory basis. LDAP (2008) also initiated a voluntary deposit scheme for electronic journals, building on the existing JCLD pilot scheme. LDAP developed a definition for electronic journals and commissioned a scoping study to identify the number and nature of UK electronic journal publications (Legal Deposit Advisory Panel 2008). Work on archiving the public web included developing cost models for the legal deposit libraries, as they would be required to "pull" web publications rather than have publishers deposit them (Legal Deposit Advisory Panel 2007). LDAP also considered the implications for publishers of web archiving.

LDAP initially recommended that deposit of offline publications should be on a self-regulated voluntary basis with libraries requesting deposits (Department for Culture, Media and Sport 2009, p. 8). Given that this category of publications was considered to be in decline, it was felt that it was unnecessary to introduce statutory deposit (Gibby and Green 2008, p. 61). The Government reserved the right to regulate at a later stage if the scheme was not achieving comprehensiveness. The Government consulted on LDAP's recommendation that harvesting and archiving of freely available online material should be regulated to ensure a more comprehensive national archive. A UK Web Archiving Consortium (UKWAC) pilot had shown that a voluntary scheme involving proactive harvesting by libraries would be hampered by copyright clearance issues (Department for Culture, Media and Sport 2009, p. 10). Regulation was supported as the least onerous option by responses to an LDAP survey of both commercial and non-commercial publishers that had participated in the UKWAC harvesting pilot (Department for Culture, Media and Sport 
2009, p. 15). LDAP's work on electronic journals was expanded to examine technical, commercial and other issues of deposit for protected online publications more generally (Legal Deposit Advisory Panel 2009). LDAP delivered its recommendation to government for deposit of this category of publications in March 2010 (Department for Culture, Media and Sport 2010b, p. 4) and was wound up in July 2010.

\section{The Legislative Process}

The Government then drafted and consulted on proposed regulations (Department for Culture, Media and Sport 2010a). The draft Legal Deposit Libraries (Non-print Publications) Regulations 2011 stated that where a publication was available in print and non-print versions, the print publication should be deposited. Where non-print publications were available in more than one medium, the libraries and publishers should agree on the medium to be deposited. If this could not be agreed, it was up to the publisher to decide. The draft Regulations included offline publications. The accompanying impact assessment (Department for Culture, Media and Sport 2010b) stated that the reason for this was to protect both publishers and libraries from legal liabilities, including breach of contract, copyright infringement and defamation actions that might arise from legal deposit activities. The provisions for online publications (ss. 14, 17, 20) referred to "delivery" of material, suggesting publishers should deposit material made freely available on the web, although this was not clear as requests for deposit could be made by a web harvester (ss. $16 \& 19$ ). The Regulations set out a range of activities that could be performed on deposited publications by legal deposit libraries. These proposals included provisions to ease the economic impact on publishers. For example, only one person at a time in each deposit library could view a publication (s. 23) and publishers could request embargoes of up to three years on access to deposited publications (s. 25$)^{6}$.

\footnotetext{
${ }^{6}$ By 2017, eleven publishers had requested an embargo (Joint Committee on Legal Deposit 2018, p. $40)$. It is not clear how many publications were involved.
} 
During 2011, the Government revised the draft Regulations in response to the results of its 2010 consultation (Department for Culture, Media and Sport, 2010a). It seemed that not enough evidence had been provided to show that the Regulations would not impose a disproportionate cost burden on publishers (Department for Culture, Media and Sport 2011). Publishers had concerns over various issues including technological implications, security, the need for multiple deposits and access and use of deposited publications (Department for Culture, Media and Sport 2011). The new draft Legal Deposit Libraries (Non-print Works) Regulations 2013 (Department for Culture, Media and Sport 2012a) addressed some, if not all, of the concerns raised by publishers. A key revision was to remove any obligations on publishers to deliver online publications directly to legal deposit libraries. Publishers would, however, have to provide libraries with the ability to harvest protected publications, for example by providing login information. The revised Regulations provided exemptions from depositing offline publications or providing login details for micro businesses (10 employees or fewer) to relieve a disproportionate cost burden on them (Legal Deposit Libraries (Non-print Works) Regulations 2013, ss. 19-20). However, these provisions would expire in March 2014 (Department for Culture, Media and Sport 2012a, p. 8). The draft Regulations introduced flexibility for deposit of protected online publications by agreement between the publishers and libraries. They included provision for secure upload of protected publications by publishers on a voluntary basis and to revert back to the default of library harvesting if desired (Department for Culture, Media and Sport 2012a, p. 14). The consultation document on the revised Regulations included guidance to publishers on how the law would apply to them and to address concerns on security (Department for Culture, Media and Sport 2012a).

The Government noted that there was general support for legal deposit in the response to its consultation (Department for Culture, Media and Sport 2012b, p. 2). However, it also highlighted remaining concerns of libraries and publishers and proposed the introduction of some further minor revisions and guidance to address the concerns that it accepted 
(Department for Culture, Media and Sport 2012b, p. 2). The Government proposed to explicitly exclude audiovisual material in the Regulations (Department for Culture, Media and Sport 2012b, p. 3). It also indicated that other concerns should be dealt with mainly through the development of policies and procedures and through JCLD deliberations (Department for Culture, Media and Sport 2012b, p. 33). The legal deposit libraries would develop a coordinated collections policy to address concerns over the potential impact of multiple web harvester requests (Department for Culture, Media and Sport 2012b, p. 3). The libraries would also have to provide a longer notice period for publishers to respond to requests for login details or to provide content via another delivery method (Department for Culture, Media and Sport 2012b, p. 4). The Regulations would make it clear that the libraries could only use legal deposit material for non-commercial purposes (Department for Culture, Media and Sport 2012b, p. 5). The Government deferred taking any action in response to libraries' and researchers' concerns (Department for Culture, Media and Sport 2013) that access restrictions would apply to material even after it is out of copyright on the basis that this is not an immediate problem (Department for Culture, Media and Sport 2012b, p. 8). The final version of the regulations came into force on the $6^{\text {th }}$ of April 2013 (The Legal Deposit Libraries (Non-Print Works) Regulations 2013 (S.I. 2013/777)).

\section{Developing a Workable Approach to Electronic Deposit}

The guidance given to publishers on the libraries' web sites (for example British Library [2019a]) indicates that electronic legal deposit will be gradual, transitioning from print to digital publications over time. The guidance also describes the dispute resolution process that has been put in place case of disagreements between libraries and publishers (British Library [2019b]).

The legal deposit libraries developed an initial collecting plan for 20132014 (Agency for the Legal Deposit Libraries [2019a]), and then another for 2015-2020 (Legal Deposit Librarians Committee 2015). The initial plan 
acknowledged that offline publications were already collected under the voluntary deposit scheme and that the legislation meant no significant change to the collection of these publication categories (Agency for the Legal Deposit Libraries [2019b]). It also set out how and when web crawls are carried out and several alternative approaches to deposit of electronic journals. This included the BL working with third party service providers, such as Portico ${ }^{7}$ for journals and Ingram $^{8}$ for eBooks. Ingram offers ebook distribution services to publishers and supply services to libraries. Portico provides preservation services for both publishers and libraries. Publishers deposit their content with Portico, which acts as a dark archive until a trigger event, such as the closure of a publisher, occurs and the triggered publications are made accessible. This arrangement means that publishers depositing their journals can authorise Portico to supply publications in preservation formats with associated metadata.

For publishers of journals in other formats, the plan was for the $B L$, National Library of Scotland (NLS) and National Library of Wales (NLW) to approach publishers to arrange deposit, either through acquiring login details or through publishers using a secure deposit portal set up by the libraries (British Library 2019a). In the 2013-2014 period, the priority for eBooks was to collect publications in the ePub format, with other formats being accepted (Agency for the Legal Deposit Libraries [2019a]). For news and magazines published online, the plan was for a higher frequency of crawls to ensure frequently updated content is collected and also to explore other means of collecting content with publishers. Other types of publication likely to present more challenges were a lower collection priority but with the possibility of proceeding on an experimental basis with publishers.

The 2015-2020 framework is a more detailed collection development plan, acknowledging the size and complexity of the task and the resource constraints. The top priority is publications that only exist in digital form

\footnotetext{
${ }^{7}$ www.portico.org

${ }^{8} \mathrm{https}$ //Www.ingramcontent.com/
} 
at risk of outright loss (Legal Deposit Librarians Committee 2015, [p. 1]). An interesting point at the end of this document is that voluntary deposit of sound recordings is decreasing and that there may be renewed efforts to extend legal deposit to digital sound recordings (Legal Deposit Librarians Committee 2015, [p. 5]). A similar point is made about exploring with stakeholders whether "non-traditional" publications such as apps and games could collected in a selective way and preserved, although not necessarily by legal deposit libraries (Legal Deposit Librarians Committee 2015, [p. 5]).

Publishers' concerns over security (Department for Culture, Media and Sport 2011) have been addressed through a joint security undertaking by the legal deposit libraries (Gibby 2013). This document provides details of the technical and security arrangements for the legal deposit library technical infrastructure. It also explains how the libraries will ensure that access and use of legal deposit copies will comply with the provisions of the Regulations.

While implementation of digital deposit is developing gradually, progress has been made in developing policy, procedures and the infrastructure required. The legislation has now been in force for five years and so it is worth examining how the system is working in practice and what the impact of digital deposit has been on publishers so far.

\section{The Impact of Electronic Legal Deposit on Publishers}

The impact of digital legal deposit on publishers has been addressed in a post implementation review of legal deposit of non-print publications submitted by the JCLD to the UK Government in 2018. The review drew on data gathered from both the legal deposit libraries and publishers depositing non-print publications (Joint Committee on Legal Deposit 2018, p. 17). One aim was to evaluate how successfully the Regulations have met the policy objectives they were meant to address. The review report points out that the implementation is taking place in stages and therefore the conclusions are based on progress so far. There is agreement between 
libraries and participating publishers that the implementation of the Regulations has been successful in terms of collection and preservation of non-print publications (Joint Committee on Legal Deposit 2018, p. 44). Fifty-eight per cent of deposits are now in digital form and the infrastructure in place has increased the efficiency of the deposit process (Joint Committee on Legal Deposit 2018, p. 9). There have been some issues, for example, libraries are still collecting printed newspapers, as it has not hitherto been possible under the law to collect digital facsimilies and news web sites do not fully replicate the print publications (Joint Committee on Legal Deposit 2018, p. 23). The review recommends that the collection of digital facsimilies should be pursued. The conclusion on effective preservation is supported by an external validation by the Digital Preservation Coalition (Joint Committee on Legal Deposit 2018, p. 26).

The paucity of data makes it difficult to compare actual set-up costs for the publishers with between $£ 1.9$ and $£ 4$ million projected for the first ten years of electronic legal deposit (Impact assessment for the Legal Deposit Libraries (Non-Print Works) Regulations 2013 (2012), p. 14). A questionnaire survey sent to just over 500 traditional publishers resulted in a response rate of $25 \%$ (Joint Committee on Legal Deposit 2018, p. 28 ), so the results may not be representative. The majority of respondents reported no set up costs and the review report assumes that any costs were modest enough to be absorbed into general business costs (Joint Committee on Legal Deposit 2018, p. 28). Seven of the ten respondents who did provide figures for set-up costs were micro companies who reported costs between less than $£ 49$ and $£ 1,000$ (Joint Committee on Legal Deposit 2018, p. 28). These respondents did not indicate whether they felt that these costs were onerous. There were no set-up costs for web publishers as the libraries harvest web publications (Joint Committee on Legal Deposit 2018, p. 29). If the review's estimate that the overall set-up costs for publishers will be between $£ 30,000$ and $£ 2 \mathrm{~m}$ in the first ten years of legal deposit (Joint Committee on Legal Deposit 2018, p. 29), this will be significantly lower than the original projected figures and a tiny fraction of the profits generated by the publishing industry. The report states that none of the potential 
administrative costs identified by publishers, such as the provision of logins, effect of harvesting on performance, or the need to present access to personal or confidential data, have materialised (Joint Committee on Legal Deposit 2018, p. 29).

The publisher questionnaire did not directly ask publishers to quantify the costs of depositing publications (Joint Committee on Legal Deposit 2018, p. 59). Therefore it is not possible at this stage to confirm quantitatively whether projected cost savings of electronic deposit have been realised (Impact assessment for the Legal Deposit Libraries (Non-Print Works) Regulations 2013 (2012), p. 14). The review does address potential benefits to publishers from the transition from print to electronic deposit. Sixty-two percent of questionnaire respondents indicated that they had made cost savings. Twenty-nine percent of respondents were not able to say whether they had realised any cost savings (Joint Committee on Legal Deposit 2018, p. 34). The remaining $9 \%$ of respondents were either still depositing some or all of their publication in print form or were digital only publishers (Joint Committee on Legal Deposit 2018, p. 34). Cost benefits were achieved by both large and smaller publishers. Large publishers reported annual savings in excess of the initial start-up costs (Joint Committee on Legal Deposit 2018, p. 34). These savings included staff time, printing, shipping and administrative costs.

Publishers express willingness to engage with deposit of a wider range of materials (Joint Committee on Legal Deposit 2018, p. 60). Collection of more complex digital materials is likely to present challenges because of the technological complexities involved and the need to keep up with a high rate of innovation (Joint Committee on Legal Deposit 2018, p. 40). As noted in the legal deposit libraries' joint collecting framework, these challenges will need exploration (Legal Deposit Libraries Committee 2015) and adequate funding to support this (Joint Committee on Legal Deposit 2018, p. 40). 
The post implementation review paints a reasonably positive picture of a preference for electronic deposit and some indication of efficiency and cost savings. In contrast with the period during which new legislation was introduced, there is a lack of public discussion on how publishers feel about the impact of electronic legal deposit in the trade press or by trade associations. The publishers' report to the review, however, does temper the success of the implementation to an extent. It notes the limited nature of the data available regarding impact of electronic legal deposit (Joint Committee on Legal Deposit 2018, p. 59). A more realistic assessment will only emerge over time as the legal deposit libraries extend the scope of electronic deposit to a wider range of publications.

There have been no complaints from publishers depositing electronic publications, so it is assumed that the costs have not been prohibitive so far (Joint Committee on Legal Deposit 2018, p. 59). The dispute resolution procedure has not been used (Joint Committee on Legal Deposit 2018, p. 19). The systems in place to enforce the statutory access restrictions to legal deposit material are reported to be working well (Joint Committee on Legal Deposit 2018, p. 33). The independent arbitrator appointed to the JCLD has stated that her role has been conciliator within the JCLD rather than between legal deposit libraries and depositing publishers (Joint Committee on Legal Deposit 2018, Appendix B).

Despite all this, there remain significant in perspectives on the matters of access and use between libraries and publishers. The publishers' submission to the review states that "the use of materials for purposes other than preservation is seen by the Publishers as falling outside the scope of the legal deposit legislation" as the purpose of legal deposit is to "not to provide an alternative route of general non-prescribed access for users or a commercial opportunity for the libraries" (Joint Committee on Legal Deposit 2018, p. 58). Publishers believe that legal deposit provides an archive of last resort when publications are no longer available by other means (Joint Committee on Legal Deposit 2018, pp. 61 and 67). 
The publisher report does not make it clear why publishers are concerned about libraries commercially exploiting legal deposit, but the potential for libraries to act as competitors by providing access to publications has also been raised about inter-library loans (Electronic Publishing Services 2002, p. 42). The libraries report to the post implementation review refers to the possibility of libraries commercially exploiting material in their collections when copyright expires (Joint Committee on Legal Deposit 2018, p. 53). While anyone would be able to do the same with any out of copyright publication, the libraries will have large collections easily to hand.

There was some discussion on access restrictions before the new Regulations were implemented. Green (2012, p. 10) pointed out that the concerns raised about legal deposit of non-print publications reflect the interests of commercial publishers. Gibby and Brazier (2012, p. 367, 373) note that the aim of access restrictions for material harvested from the open web was to protect advertising income. The publishers report to the post implementation review reiterates the point made by Gibby and Brazier (Joint Committee on Legal Deposit 2018, p. 61). There are signs that non-commercial online publishers will have a voice in ongoing library and publisher cooperation on legal deposit. The BL's web page for the JCLD suggests that there is an intention to expand its membership or at least consult with non-traditional publishers, such as bloggers, as well as trade bodies and "official" publishers (British Library 2019b).

Publishers believe that questions of access should be subject to consultation separately from the post-implementation review process (Joint Committee on Legal Deposit 2018, p. 59). This suggestion is consistent with the view articulated throughout the publisher report to the post implementation review that preservation and access should be considered separately, and that the purpose of legal deposit collections is preservation and not an alternative access route to currently available material (Joint Committee on Legal Deposit 2018, p. 58).

\section{The Place of Electronic Legal Deposit in a Developing Publishing}

\section{Landscape}


In their report to the post implementation review, the publishers challenge the legal deposit library proposals on access and use of openly available online publications (Joint Committee on Legal Deposit 2018, pp. 60-68). The library concerns reflect changes in scholarly communication, the publishing environment, how researchers carry out research, and user expectations. The publishers do not accept that such expectations "should necessarily be the driver for use of another party's digital content" (Joint Committee on Legal Deposit 2018, p. 58).

The publishers' concerns over access extend to material harvested from the open web (Joint Committee on Legal Deposit 2018, pp. 74-75), but analysis of the content of social media sites and of multimedia sources, such as YouTube, is increasingly important in research. The recent scandal associated political use of data harvested from social media sites such as Facebook (Cadwalladr and Graham-Harrison 2018) highlights what a rich source of information these sites provide for research as well as the legal and ethical issues this practice raises. The publishers object to the legal deposit libraries proposal to make the legal deposit open web archive available online (Joint Committee on Legal Deposit 2018, pp. 74-75). Despite its limited geographical scope the UK Web Archive could be a useful research resource, particularly over the long-term as online content disappears from the open web.

While much content available on the open web is subject to copyright and monetised, the open access movement is changing how publications are being made available (Davis, P.M. and Walters, W.H. 2011; Laakso and Björk 2012; Solomon, D.J. 2013, Alahar 2017) and it may be more difficult to justify restricting access to open access publications in legal deposit collections. These publications are typically made available under a Creative Commons licence ${ }^{9}$ which allows the copyright holder to specify what can be done with the output. The UK's current legal deposit provisions mean that access to such outputs will be restricted, which is

\footnotetext{
${ }^{9} \mathrm{https}: / /$ creativecommons.org/licenses/
} 
contrary to the licence provisions and the purpose of open access. In the UK, UKRI (formerly Research Councils UK), the public body supporting research across the country, initiated an open access policy in 2005 (UK Research and Innovation 2013). This policy acknowledges that free and open access to publicly funded research is a societal good (UK Research and Innovation 2013 , p. 1). The policy has been supported by funding to some institutions to pay for research publications to be immediately openly available by under the Gold Open Access route ${ }^{10}$. The policy is also being partially enforced by the requirement for open access for some categories of research outputs to be submitted to the UK's next Research Excellence Framework exercise (REF 2021). ${ }^{11,12}$ Future discussions over access and use of content in legal deposit libraries should consider what to do about open access publications as well as those that are out of copyright ${ }^{13}$.

Open access is an element of the broader concept of open science. While there does not yet seem to be a single accepted definition of open science ${ }^{14}$, it also encompasses open data, notebooks and educational resources as part of a new approach to scientific methods, collaboration and access to knowledge. Open science implies that source materials are published alongside working records and traditional research outputs. Indeed, some UK research funders require applications for research grants to include data management plans setting out how digital outputs will be managed and made available ${ }^{15}$. If such materials are considered to be published, what, if any, role legal deposit has in preserving access to these sources will need to be addressed.

\footnotetext{
${ }^{10} \mathrm{https}$ //www.ukri.org/funding/information-for-award-holders/open-access/open-access-policy/openaccess-block-grants/

${ }^{11} \mathrm{http}: / / \mathrm{www} \cdot h$ efce.ac.uk/rsrch/oa/

$12 \mathrm{http}: / /$ www.hefce.ac.uk/rsrch/oa/Policy/

${ }^{13}$ For a broader discussion on the future of scholarly communication and preservation and the preservation of scholarly outputs see Fitzpatrick, K., 2011. Planned obsolescence: publishing, technology, and the future of the Academy. NYU Press.

${ }^{14}$ The OECD describes the concept at http://www.oecd.org/sti/inno/open-science.htm

${ }^{15}$ For example, see http://www.dcc.ac.uk/resources/data-management-plans/fundersrequirements for examples of funder requirements.
} 
Researchers are applying analysis tools to draw new insights from large corpuses of scientific, medical, social, financial, statistical data and texts. In 2014, the UK introduced a new copyright exception for text and data analysis for non-commercial research (Copyright, Designs and Patents Act 1988 , s. 29A). This exception allows researchers with lawful access (for example they, or their institution, already has a subscription) to works to make a copy for analysis for non-commercial research as long as they provide an acknowledgement where possible. No further unauthorised copying or sharing of content is allowed. Responses to the UK Government's consultation on the proposal to introduce this exception indicated that it was unpopular with publishers who would prefer to only allow this activity under licence (HM Government 2012, p. 17). The legal deposit libraries argue that legal deposit and copyright laws should be aligned so that changes to copyright law also apply to legal deposit publications (Joint Committee on Legal Deposit 2018, pp. 53-54). The publishers stated that researchers do not need to use legal deposit collections for this purpose (Joint Committee on Legal Deposit 2018, p. 61 ) and that this should be done through individual purchase or subscription, library provision and text and data analysis agreements.

\section{Conclusion}

It seems that publishers acknowledge the benefit of legal deposit as a means of preserving the UK's published output for posterity. There is also encouraging, if limited, evidence that deposit of electronic publications is not imposing an onerous burden, at least on larger publishers. Indeed, there is evidence to suggest that publishers find electronic deposit to be more efficient. There have been no formal complaints from publishers to the JCLD about the implementation of electronic legal deposit and no need for dispute resolution between publishers and legal deposit libraries, so far. There does not seem to be any evidence of public discussion about the impact of electronic legal deposit on publishers (although this may be happening privately) since implementation. The publishers' formal report to the post implementation review indicates willingness to continue to work to expand the scope of electronic deposit to more complex digital 
materials. For now, electronic legal deposit seems to be a positive thing for the publishers involved.

However, publishers are concerned that legal deposit collections could be used in ways that interfere with their commercial interests. While the current UK legal deposit legislation aims to balance the interests of different stakeholders, the provisions relating to access and use of legal material are meant to protect these interests. It is understandable that publishers wish to be free to develop products and services based on the content they publish. What is not clear at the moment is whether access restrictions must be applied across the board and in perpetuity, or whether arrangements can be put in place to reflect the diversity in digital publishing so that, for example, material that is openly licensed can be made freely available by legal deposit libraries. It does not make sense that access restrictions should continue after publications enter the public domain, despite publisher concerns about unfair competition.

The tension around access and use, always inherent in legal deposit, but impressively handled so far thanks to good working relationships between the libraries and publishers, could become far more acute over time because of the rise of open access and the user expectations the deposit libraries wish to meet. There seems to be a willingness on the part of publishers to open up areas of disagreement to wider consultation, which may lead to compromises and more nuanced access and use permissions in practice. Developments in scholarly communication and open science may also result in a more accessible and usable national published archive, at least for scholarly outputs. Whether this archive is part of a national legal deposit collection or not remains to be seen.

\section{References}

AGENCY FOR THE LEGAL DEPOSIT LIBRARIES, [2019a]. Electronic legal deposit: legal deposit libraries' collecting plans for 2013-2014. Available from: https://www.legaldeposit.org.uk/electronic/2013-2014-collectingplans.html (accessed 9 September 2019). 
AGENCY FOR THE LEGAL DEPOSIT LIBRARIES, [2019b]. Electronic legal deposit. Available from: https://www.legaldeposit.org.uk/electronic/index.html (accessed 9 August 2018).

ALAHAR, H., 2017. Academic publishing, internet technology, and disruptive innovation. Technology Innovation Management Review, 7(11), pp. 47-56.

ALTICK, R.D., 1957. The English common reader: a social history of the mass reading public 1800-1900. Chicago: University of Chicago Press. ASSOCIATION OF ONLINE PUBLISHERS, 2019. About us. Available from: https://www.ukaop.org/about (accessed 9 September 2019). BRITISH LIBRARY, 1996. Proposal for the legal deposit of non-print publications to the Department of National Heritage from the British Library. London: British Library.

BRITISH LIBRARY, [2019a]. How to deposit your digital publications. Available from: https://www.bl.uk/help/how-to-deposit-your-digitalpublications (accessed 9 September 2019).

BRITISH LIBRARY, [2019b]. Joint Committee on Legal Deposit. Available from: https://www.bl.uk/legal-deposit/joint-committee (accessed 9 September 2019).

BROWN, D.J. and BOULDERSTONE, R., 2008. The impact of electronic publishing: the future for publishers and librarians. Rev. ed. München: K.G. Saur.

CADWALLADR, C. and GRAHAM-HARRISON, E., 2018. Revealed: 50 million Facebook profiles harvested for Cambridge Analytica in major data breach. The Guardian, 17 March. Available from:

https://www.theguardian.com/news/2018/mar/17/cambridge-analytica-facebookinfluence-us-election (accessed 9 September 2019).

Copyright, Designs and Patents Act 1988, ch. 48.

Davis, P.M. and Walters W.H., 2011. The impact of free access to the scientific literature: a review of recent research. Journal of the Medical Library Association, 99(3), pp. 208-217.

DEEGAN, M. and SUTHERLAND, K., 2009. Transferred illusions: digital technology and the forms of print. Aldershot: Ashgate.

DELLAR, G., 2001. Legal deposit accounted for. Letter to the editor. Library Association Record, 103(9), p. 542. 
DEPARTMENT FOR CULTURE, MEDIA AND SPORT, 2009. Proposal on the collection and preservation of UK offline and microform publications and UK online publications: (available free of charge and without access restrictions). Available at: accessed 9 September 2019/ (accessed 9 September 2019).

DEPARTMENT FOR CULTURE, MEDIA AND SPORT, 2010a. Consultation on the legal deposit of non-print works. Available from:

http://webarchive.nationalarchives.gov.uk/20110505103427/http://www. cep.culture.gov.uk/consultations/7449.aspx (accessed 9 September 2019).

DEPARTMENT FOR CULTURE, MEDIA AND SPORT, 2010b. Digital legal deposit - non-print off line publications. Impact Assessment DCMS 004. Available from:

http://webarchive.nationalarchives.gov.uk/20110505103427/http://www. cep.culture.gov.uk/consultations/7449.aspx (accessed 9 September 2019).

DEPARTMENT FOR CULTURE, MEDIA AND SPORT, 2011. Government response to the public consultation on the draft regulations and guidance for non-print legal deposit [online]. Available from:

http://webarchive.nationalarchives.gov.uk/20110505102314/http://www.cep.culture.g ov.uk/publications/8029.aspx (accessed 9 September 2019).

DEPARTMENT FOR CULTURE, MEDIA AND SPORT, 2012a. Consultation on the Legal Deposit of Non-Print Works 24 February 2012 [online]. Available from:

http://webarchive.nationalarchives.gov.uk/20121204120059/http://www.culture.gov.u k/consultations/8878.aspx (accessed 9 September 2019).

DEPARTMENT FOR CULTURE, MEDIA AND SPORT, 2012b. Government response and summary responses to the consultation on the legal deposit of non-print works. Available from:

http://webarchive.nationalarchives.gov.uk/20121204125554/http://www.culture.gov.u k/images/publications/LDL2012-Government-Response.pdf (accessed 9 September 2019).

DEPARTMENT FOR CULTURE, MEDIA AND SPORT, 2013. Public Responses to the draft Legal Deposit Libraries (Non-print works) Regulations 2013 
consultation [online] Available from:

http://webarchive.nationalarchives.gov.uk/20130125115813/http://www.culture.gov.u k/consultations/9314.aspx (accessed 9 September 2019).

ELECTRONIC PUBLISHING SERVICES LTD, 1996. The legal deposit of online databases. British Library R\&D Report 6244. London: British Library Research and Development Department.

ELECTRONIC PUBLISHING SERVICES LTD, 2002. The impact of the extension of legal deposit to non-print publications: assessment of cost and other quantifiable impacts: study report prepared for the Joint Committee on Voluntary Deposit. London: EPS Ltd.

ELECTRONIC PUBLISHING SERVICES LTD, 2006. Refining the map of the universe of electronic publications potentially eligible for legal deposit. London: Electronic Publishing Services Ltd.

FEATHER, J.P., 1994. Publishing, piracy and politics: an historical study of copyright in Britain. London: Mansell.

FELL, C., 2004. Legal deposit libraries bill - update. (No longer available from: http://www.alpsp.org/legdep.htm).

GIBBY, R., 2013. Undertaking to the Joint Committee on Legal Deposit on the security of deposited non-print publications. Available from:

https://www.bl.uk/aboutus/legaldeposit/websites/security/joint_security_ undertaking.pdf (accessed 9 September 2019).

GIBBY, R. and BRAZIER, C., 2012. Observations on the development of non-print legal deposit in the UK. Library Review, 61(5), pp. 362-377. GIBBY, R. and GREEN, A., 2008. Electronic legal deposit in the United Kingdom. New Review of Academic Librarianship, 14(1-2), pp. 55-70. GREEN, A., 2012. Introducing electronic legal deposit in the UK: a Homeric tale. Alexandria, 23(3), pp. 103-109.

HARRIS, P.R., 1991. The library of the British Museum: retrospective essays on the Department of Printed Books. London: British Library. HENDLEY, T., 1996. The preservation of digital material. British Library R\&D report 6242. London: British Library Research and Innovation Centre. HM Government, 2012. Consultation on copyright: summary of responses June 2012. Available from:

https://www.gov.uk/government/uploads/system/uploads/attachment_data/file/320223 
/copyright-consultation-summary-of-responses.pdf (accessed 9 September 2019).

Impact assessment for the Legal Deposit Libraries (Non-Print Works) Regulations 2013 (2012). Available from:

https://www.legislation.gov.uk/ukia/2013/1017/pdfs/ukia_20131017_en.pdf (accessed 9 September 2019).

JOINT COMMITTEe ON LEGAL DEPOSIT, 2018. Post Implementation Review of the Legal Deposit Libraries (Non-Print Works) Regulations 2013. Joint Committee on Legal Deposit. Available from: https://www.gov.uk/government/publications/post-implementationreview-of-the-legal-deposit-libraries-non-print-works-regulations-2013 (accessed 9 September 2019).

LAAKSO, M. and BJÖRK, B.-C., 2012. Anatomy of open access publishing: a study of longitudinal development and internal structure. BMC Medicine, 10(124). Available from:

https://bmcmedicine.biomedcentral.com/track/pdf/10.1186/1741-7015-10-124 (accessed 9 September 2019).

LEGAL DEPOSIT ADVISORY PANEL, 2006. Legal Deposit Advisory Panel Annual Report September 2005 - August 2006. Available from:

http://webarchive.nationalarchives.gov.uk/20071207231619/http://www. culture.gov.uk/Reference_library/Publications/archive_2007/Idap_annualr eport07.htm ?textOnly $=$ False\&textOnly $=$ False\&textOnly $=$ False\&textOnly $=F$ alse\&textOnly =False\&textOnly=False \&contextId $=\{$ 99EE2DEC-C291-4937A64E-1F0C5F12D32B\} (accessed 9 September 2019).

LEGAL DEPOSIT ADVISORY PANEL, 2007. Legal Deposit Advisory Panel Annual Report September 2006 - August 2007. Available from:

http://webarchive.nationalarchives.gov.uk/20090902213611/http:/www.cep.culture.g ov.uk/what_we_do/libraries/3409.aspx (accessed 9 September 2019). LEGAL DEPOSIT ADVISORY PANEL, 2008. Legal Deposit Advisory Panel Annual Report September 2007 - August 2008. Available from: http://webarchive.nationalarchives.gov.uk/20090902220855/http://www. cep.culture.gov.uk/reference_library/publications/6167.aspx (accessed 9 September 2019). 
LEGAL DEPOSIT LIBRARIANS COMMITTEE, 2015. Joint Collecting

Framework for UK Legal Deposit, 2015-2020. Available from:

https://www.bl.uk/britishlibrary/ /media/bl/global/legal\%20deposit/joint-collectingframework-for-uk-legal-deposit.pdf ( accessed 9 September 2019).

Legal Deposit Libraries Act 2003, ch. 28.

The Legal Deposit Libraries (Non-print Publications) Regulations 2011.

Available from:

http://webarchive.nationalarchives.gov.uk/20110505103427/http://www. cep.culture.gov.uk/consultations/7449.aspx (accessed 9 September 2019).

The [draft] Legal Deposit Libraries (Non-print Works) Regulations 2013. Available from:

http://webarchive.nationalarchives.gov.uk/20121204120059/http://www. culture.gov.uk/consultations/8878.aspx (accessed 9 September 2019).

The Legal Deposit Libraries (Non-Print Works) Regulations 2013 (S.I. 2013/777).

MARTIN, D., 1996. Definitions of publications and associated terms in electronic publications. British Library R\&D Report 6243. London: British Library Research \& Development Department.

MARTIN, W.J. and TIAN, X., 2010. Books, bytes, and business : the promise of digital publishing: Farnham: Ashgate.

MILLS WADE, A., 2003. In: British Library, 2003. Historic change in legal deposit law saves electronic publications for future generations - Bill to extend legal deposit to UK non-print materials receives Royal Assent. Press release 31 October 2003.

MUIR, 2005. Legal deposit of digital publications (Phd thesis, Loughborough University). Available from:

https://dspace.lboro.ac.uk/dspace-

jspui/bitstream/2134/8469/2/Thesis_Adrienne_Muir.pdf (accessed 9

September 2019).

PUBLISHERS ASSOCIATION, 2018. Digital growth drives value of UK publishing industry to E6bn. Available from: https://www.publishers.org.uk/news/releases/2019/pa-publishingyearbook-2018/ (accessed 9 September 2019). 
RAMRATTAN, L. and SZENBERG, M., 2016. Revolutions in book publishing: the effects of digital innovation on the industry. Basingstoke: Palgrave. SOLOMON, D.J., 2013. Digital distribution of academic journals and its impact on scholarly communication: looking back after 20 years. The Journal of Academic Librarianship, 39(1), pp. 23-28.

UK RESEARCH AND INNOVATION, 2013. RCUK policy on open access and supporting guidance. Available from:

https://www.ukri.org/files/legacy/documents/rcukopenaccesspolicy-pdf/ (accessed 9 September 2019).

WHITAKER, D., 2001a. Time to move on - free legal deposit has had its day. The Bookseller, 18 May, 24-25.

WHITAKER, D., 2001b. Nobody expects the Spanish Inquisition. Library Association Record, 103(8), pp. 492-493.

WORKING PARTY ON LEGAL DEPOSIT, 1998. Report of the Working Party on Legal Deposit. Available from:

http://www.bl.uk/aboutus/stratpolprog/legaldep/report/ (no longer available).

WORKING PARTY ON LEGAL DEPOSIT, 1999. Code of practice for the voluntary deposit of non-print publications. Revised version, September 1999. 